DOI 10.14746/ssp.2019.3.5

Marzena BARAŃSKA

Jagiellonian University

\title{
Management of Television Advertising Content Based on the Value of Health
}

\begin{abstract}
The world in which people live is a collection of values created by them and for them. As free beings, people make choices, are constantly guided by them in their daily behavior and attitudes, recognizing them as valuable and worthwhile. Accepted socially or individually, they influence decisions made in economic, aesthetic, moral, legal, cognitive or religious spheres. Their importance and influence were also noted by the authors of advertising messages. Appropriately tailored to the market, they shape the content of advertising messages and are of significance in business communication with consumers. This phenomenon can especially be noted in messages recommending medications. Appealing or referring to a particularly valued quality such as "health" is not only justified, but it allows buyers to select these products which in their opinion guarantee the achievement of well-being, a disease-free condition. Management of advertising content through a kind of "imaging" of health in commercials is a consequence of the use of various means of persuasion.
\end{abstract}

Key words: marketing management, value, health, television advertising

\section{Introduction}

7 he creation of an efficient and effective advertising message requires the selection of an effective argument that will make the content recipient behave as expected by the message sender. With increasing frequency, the storyline of the commercial is the result of interdisciplinary studies. Sociologists, lawyers, cultural studies experts, analysts and philosophers contribute to the campaign model solution. Knowledge of the needs and expectations of the message recipients, their goals and aspirations, becomes helpful in creating the message storyline. A special role is assigned to all values held in high regard in a given society. Their instrumentalisation in commercial communications is seen as an effective form of impact on consumer behavior, especially when they remain in submission to their valuation by individuals and by society - the recipients of content. The analysis of the hierarchy of values test results found health 
to be especially valuable, not only perceived as a value in itself, but as a collection of concepts contributing to the value of health. Terms such as prevention, health care, disease-free condition, health of an individual, public health - have become an inherent part of the concept of health, but have also contributed to the undertaking of marketing activities which are not always focused on education, but also possess a mercantile dimension. In this context, the scale of advertising of pharmaceutical products confirms that the market for this type of goods occupies a prominent position in the Polish economy. As a result of the dynamics of development, the broadcast advertising content does not always correspond to the prescribed boundaries of allowable practices. Content management in advertising encourages not only the search for effective forms and tools of influence, but also the selection of those which were not eliminated through the introduced normative and beyond-normative boundaries.

The aim of this publication is a discussion of selected issues pertaining to the instrumentalization of the value of health in the process of advertising content management and its impact on consumer behavior and attitudes. Searching for answers to the research question, "To what extent are health values created by the content of pharmaceutical product advertising and what are its determinants?" - content analysis was utilized. The application of observation, statistical method and exegesis of legal texts was also helpful.

\section{The Concept of Values}

The materialistic and non-materialistic dimension of human life is inextricably linked to values. The term "value" has multiple meanings in the Polish language. Analyzed from a sociological, economic, legal, etc. perspective, they reflect what is socially valued by both individuals as well as entire communities.

The immanent trait of man is the ability to understand which, as Aristotle rightly emphasizes, distinguishes man from other earthly beings (Arystoteles, 1972). Comprehension - allows a person to make a thorough analysis of the world, its understanding, the pursuit of goals, desires, seeking justification for one's decisions. This behaviour is, among other factors, a result of building a system of assumptions, defining the rules of conduct of societies and the individuals forming them. Therefore, valuation for oneself and others determines an axiological approach (Sta- 
chowicz-Stanusch, 2004, p. 30). "The world of values of this creation is the scale of humanity, because only man is capable of creating or, more impartially speaking, of 'realizing values' and building culture on that foundation. Because in its essence, culture is just an appropriately hierarchical world of values and a uniquely human trait. It is impossible to understand a human being in isolation from their world of values and the resulting behaviors" (Kocik, 2006, p. 17).

The sociological dictionary states that by values we refer to "... ideas, phenomena, material and intangible objects, states of things, persons, groups, etc. positively or negatively evaluated or approved or rejected. Values are one of the main determinants and goals of human action" (Olechnicki, Załęcki, 1997, p. 239). By making decisions, the individual operates on their own account, thus forming a justification for decisions made based on a catalogue of values. The way one will use the privilege of choice depends on many factors, including a critical analysis of the environment, argumentation of the thought process. In economic terms, they are identified with income, e.g., in terms like "added value" or "creating value for the customer" or "value chain" (Górniak, 2015, p. 102). According to G. Hofstede, it is in values that the motivating factor for making specific decisions and choices can be found (Hofstede, 2000, p. 43).

$\mathrm{K}$. Blanchard emphasizes that common values and goals unite people, and the resulting linearity influences success and competitive advantage (Blanchard, 2015). Values are also an integral part of the organizational structure in modern businesses. As M. Armstrong rightly points out, "corporate culture is created by common beliefs, attitudes and values which influence the shape of activities and mutual interpersonal relationships" (Armstrong, 1998, p. 86). For this reason, it is possible to discuss not only the linearity of organizational and individual values, but also the feedback loop between "[...] suppliers and recipients of services and products, meeting the needs and delivering benefits in return for profit" (Bakalarska, 2016, s. 26). Consequently, value marketing is becoming increasingly important in marketing activities, perceived in terms of:

- creating and delivering customer value, Day (1990), Brown (1995), Naumann (1995), Cravbens (1997), Scott (1998);

- customer value, customer lifetime value, Reichcheld (1996), Kumar (2010);

- customer - perceived value, Gronoroos (1997), Anderson, Naruse (1998) (Marketing wartości). 
Value adaptation in marketing activities is a consequence of:

- identifying the service provider, the manufacturer - the company - with the highest value;

- evaluation of the product in terms of intangibles, and thus as the realization of customer needs;

- building long-term relationships with buyers conditioned by mutual trust and loyalty (Doyle, 2003).

"Customer value," "customer lifetime value" acquire a special meaning. V. Kumar identifies the management of customer value with the measurement and maximization of its value (Kumar, 2010).

"Customer value should be calculated and analyzed based on values created by customers, taking into account present and future streams over the customer lifetime value" (Dobiegala-Korona, 2006, p. 176). B. Dobiegała-Korona rightly points out that "building customer value by providing them value (benefit) must take into account a dynamic approach" (Dobiegała-Korona, 2012, p. 69). Therefore, the analysis of factors determining customer behaviour and an appropriate selection of argumentation justifies the return on investment incurred on behalf of the customers. "Recognizing human reality, both external and internal, implies valuation. Almost all conscious activities are a result of choosing specific values. The process of valuation provides goals and motives for action, while by itself being determined by the individual's orientation in the environment. It is not enough to use descriptive knowledge alone for making choices, it is also necessary to assign values to specific elements of reality" (Plopa, 2009, p. 18). Value adaptation in conducting marketing activities is a consequence of:

- identifying the service provider, the manufacturer, the company with the highest value;

- evaluation of the product in terms of terms intangibles, and thus as the realization of customer needs.

Health in normative terms is perceived as a subjective right of the individual. Therefore, both international and national solutions state it is a fundamental right of the individual, and country states are required to develop and implement solutions that ensure its highest level, including: through access to health-related goods, health care systems, but also education and promotional activities. There is a timeless dimension to the understanding of the term health developed in 1946 by the World Health Organization (WHO). A disease free state as well as well-being are key components of the concept. Following this, in 1948, the UN General As- 
sembly adopted the Universal Declaration of Human Rights (UDHR), in art. 3 guaranteeing the right to life, liberty and personal security and in Article 25 stating that "Everyone has the right to a standard of living that ensures the health and well-being for them and their family [...]" (Universal Declaration...). The prominence and importance of health are indicated, among others, in the International Covenant on Civil and Political Rights (1966), the Alma-Ata Declaration (1978), Adopted by the World Health Assembly... (1978).

The role and importance of health were also emphasized in Polish national solutions. "As a consequence, in the 1997 Constitution of the Republic of Poland (hereinafter referred to as the Constitution) the basis for the protection of the value of health is to be sought in many of its provisions, with the basic role to be attributed to art. 68 of the Basic Law. In addition, the following also apply to the obligation to protect health: Art. 30 (protection of dignity), art. 38 (protection of life), art. 39 (prohibition of experiments without voluntary consent), art. $41 \mathrm{sec}$. 1 (bodily inviolability), art. 40 (prohibition of torture and other cruel, inhuman or degrading treatment or punishment). There is no doubt that health, its protection and optimal development are ... for the individual a sine qua non condition to enjoy all other freedoms and rights" (Jarosz-Żukowska, 2014, p. 659 and n.). The concern for an individual's and society's health has been reflected in media regulations, including Directive 2010/13/EU of the European Parliament and of the Council of 10 March 2010 regarding the coordination of certain legal, regulatory and administrative regulations of Member States concerning the provision of audiovisual media services (directive on audiovisual media services), Radio and Television Broadcasting Act of 29 December 1992.

The social dimension of health obligates individuals to care for the state of their health. As demonstrated by the results of the research conducted in Poland, in the past decade the hierarchy of values has stabilized (Wartości i normy..., 2013). In 2005, 69\% of respondents rated the preservation of good health as the second highest value, and in 2010 and 2013 this figure rose to 74\% (Wartości i normy, 2013, p. 2). Reports published in 2015 indicate that "Almost all respondents rated health, family and family happiness, as well as honesty as values of high importance to them (including very high importance)." (Wartości i zaufanie społeczne...). For this reason, an individual is responsible for their disease-free condition and should do everything necessary to care for their health. The pharmaceutical companies turn out to be helpful to its maintenance, by offering 
a diverse range of medications and conviction as to the effectiveness of the product offered. "The perception of the value of health" - justifies the choices made by pharmaceutical manufacturers in terms of argumentation, product recommendation. Identification of a choice with health as well as an effective medication leading to a disease-free condition is important from the point of view of marketing management, and especially the means of persuasion utilized in advertising campaigns. The desired condition can be achieved after purchasing and consuming the medication offered.

As a consequence, what is valuable to the individual is of particular importance in determining the goals of the organization. Values are an important factor in company management, not only in the area of its organizational structure, but also in its marketing activities. Pharmaceutical companies are aware of the effectiveness of the message and are spending more and more on advertising. "According to Starlink, pharmaceutical companies spend more on advertising than banks or telecoms. In 2015 it was 5.5 billion zlotys, but in reality it could be about 1 billion zlotys" (Sudak, 2016).

Since what we want and desire refers to material goods, the consequence that follows involves creating a platform to identify the good with what is valuable, both from the perspective of an individual/buyer as well as the company/advertiser. For this reason, the value of health instrumentalized in the implemented advertising campaigns is influencing the effectiveness of the messages delivered.

\section{Management of Pharmaceutical Advertising - Selected Issues}

According to $\mathrm{Ph}$. Kothler: "Marketing is a profitable supply of customer satisfaction. The purpose of marketing is to attract new customers with a promise of superior value, and to retain existing customers by providing satisfaction." (Kotler, Armstrong, Saunders, Wong, 2001, p. 12). Achievement of these goals is the result of appropriately selected forms of influence, i.e. advertising, public relations, promotion, branding, merchandising, branch marketing, product placement and more. The term management in marketing, because of the indifferent approaches to the definition of the concept, does not have a single universally accepted definition. In the "Business and Economics Dictionary" it was defined as: "[...] any business activity oriented to satisfy customer needs and 
involving the creation of the so-called marketing orientation inside the company. This orientation is served by the use of marketing mix, marketing strategy development and marketing plan design" (Słownik biznesu i ekonomii: zarzadzanie marketingiem). According to M. Prymon, “[...] marketing management is an organized review of the issues of achieving specific market responses of other entities, through creating and offering value" (Prymon, 2001, p. 15).

This approach creates an obligation to analyze the management from the point of view of selection of information channels (media management), as well as content (content management). The choice of specific forms and media of influence is conditioned not only by type of product/service offered, the stage of the so-called "product life cycle," legal regulation interfering in the sphere of decision-making by advertisers, eliminating the universal use of both information channels and their media, but also by the preferences of potential consumers. Gerry McGovern believes that content management should be perceived as: "[...] delivering the right content, to the right person, at the right time and for the right price" (Trzaska, 2011, p. 9). Content management in advertising should be understood as the use of appropriately selected arguments and tools that influence the behavior of the message recipients within the limits permitted by law and ethics. An effective narrative referring to stereotypes, archetypes, shock, values is designed to transport a person into the world of material goods, thus satisfying their expectations or realizing their dreams (broadly: Nierenberg, 2011).

The origin of the term "advertising" is to be found in the Latin word "reclamo," "reclamare" - meaning shouting to someone, loudly opposing, echoing, bouncing, calling (Stownik tacińsko-polski, 1982, p. 421-422). The practiced usage over the centuries changed the interpretation, lending a strictly marketing dimension. Currently, priority meaning beyond normative solutions should be awarded to the concept authored by the American Marketing Association (AMA). Their definition states, "Advertising is any paid form of non-personal presentation and promotion of ideas, goods or services by an identified sponsor. Advertising is knowledge and art. Knowledge is necessary in order to know the rules connected with the fulfillment by advertising of the role of marketing communication with buyers and its psychological determinants - its perception by the recipients. The art of advertising is describing and presenting the benefits of products to buyers and inducing them to purchase through non-personal media" (Sztucki, 1998, p. 266). Exegesis of legal texts forms the basis for 
stating that advertising is that form of marketing influence which is subject to special legal regulation, in terms of content construction (subject and object limitations) as well as in the context of its dissemination, especially on television. The normative view of television advertising dictates the use of appropriate solutions tailored to the commercial audiovisual message (Article $1 \mathrm{~h}$ of the Directive of the European Parliament and Council of 10 March 2010, 2010/13/EU) Art. 4 section 6 of the Radio and Television Broadcasting Act states that "advertising is any message, not originating from the sender, aiming to promote the sale or other forms of utilization of goods or services, promotion of specific issues or ideas or achieving another effect desired by the sponsor, broadcast for a fee or other form of remuneration." (Ustawa o radiofonii i telewizji, 1992; cf.: Barańska, 2012; Barańska, 2016, p. 189-214).

The concept of advertising of a medicinal product is of fundamental importance in analyzing the problem. According to Art. 52 the pharmaceutical law recognizes as such: "[...] any activity consisting of informing or encouraging the use of a medicinal product, with the purpose of increasing: the number of prescriptions issued, supply, sales or consumption of medicinal products" (Ustawa z dnia 6 września 2001 r. Prawo farmaceutyczne).

When managing advertising content, the following criteria should be considered:

- the recipients - as a result, advertising can be classified as directed to the public or directed to persons authorized to issue prescriptions or persons engaged in sale and distribution of medicinal products (Article 52 (1) and (2) of the above Act);

- the types of activities involved: visiting persons entitled to issue prescriptions or persons involved in sale and distribution of medicinal products by commercial or medical representatives (par $2 \mathrm{pt}$ (3)) and the provision of samples of medicinal products (Article 52, paragraph 2, point 4);

- forms of influence - sponsorship of promotional meetings for persons authorized to issue prescriptions or persons involved in sale and distribution of medicinal products (paragraph $1 \mathrm{pt}(5))$ and sponsoring conferences, congresses and scientific meetings for individuals authorized to issue prescriptions or involved in sale and distribution of medicinal products (Article 52, paragraph 2, point 6).

Due to the wide scope of the issue under discussion, the author will limit her analysis to "advertisements addressed to the public" (broadly: Barańska, 2012; Harasimiuk, 2011). There is no unequivocal definition of 
the phrase used in the source literature. In the opinion of E. Harasimiuk, it refers to advertising directed to average recipients who are not persons entitled to "[...] issue prescriptions or involved in the sale and distribution of medicinal products. [...] At this point it should be emphasized that [...]" (Harasimiuk, 2011, p. 327). The scope of the concept of an average consumer in relation to this type of offer needs to be modified with regards to the criteria used to define this group in relation to other products or services. Despite the specificity of the medicinal products offered, the legislator does not provide a specific customer characteristics for this type of products or services, guided by general assumptions. However, it is clearly emphasized that advertising "[...] can not be targeted at children or include any element that is addressed to tchem [...]" (cf.: Ustawa z dnia 6 września 2001 r. Prawo farmaceutyczne). „It should be assumed that the client is a person who is sick, unwell, predominantly elderly and parents of small children, whose sensitivity, due to their state of health, is not unaffected by the critical attitude regarding the evaluation of the advertising content communicated. Such a position can lead to in making multiple concurrent purchases of products with the same effectiveness resulting from the buyer's misconception that multiplicity means health, efficiency, effectiveness" (Barańska, 2012, p. 196). The coherent dimension of the imposed regulation is justified by the situation of the sick person and their surroundings (relatives, parents, friends) - the direct and indirect addressee of the message - associated with pain, suffering, discomfort resulting from the disease condition. For obvious reasons the addressee will not be a business or an organization. It is of particular significance regarding the scope of functioning of the pharmaceutical market, because the content of economic statements addressed in specialized media - directed to medical staff - perform primarily an informational and educational function, and therefore they contain detailed information, at least in terms of composition and indication of the medication, a contrario publishing content outside of the indicated media creates an obligation to respect both the normative and beyond-normative boundaries.

\section{The Normative Dimension of Television Advertising for Pharmaceuticals}

Television, which is classified as a so called old medium, still takes a leading position considering the time that the viewers devote to 
watching it. The "Mobile and Digital Report in Poland and the World" demonstrates that "The average time that Poles spend every day on the Internet amounts to 4.4 hours on computers and 1.3 hours on mobile devices" (Mobile i digital w Polsce..., 2016), during the same period "[...] devoted to watching television (272 minutes) (Polacy coraz dtużej ogladaja telewizje...). The above information constitutes an opportunity for pharmaceutical companies promoting medications, vitamins, dietary supplements etc. to patients. Between 1997 and 2015, the advertising time increased sixfold $-24.7 \%$ of airtime devoted to advertising on TVP 1, TVP 2, Polsat and TVN was taken up by commercials for pharmaceuticals. The highest number of commercials in 2015 was broadcast on TVP2, over 54,000 , over 45,000 on TVP1 and over 34,000 on TVN and over 33,000 on Polsat (Leki a suplementy diety..., 2016). "Advertisers in the pharmaceutical and para-pharmaceutical industry spent in January 2016 almost PLN 670 million on promotion, which amounts to $94 \%$ of the total pharmaceutical sector expenditure [...] Pharmaceutical products sector spent by far the most on television advertising in the first 3 quarters of 2016 - 58 percent of its expenditure. The subsequent pieces of the advertising pie were allocated to radio (21\%), magazines (16\%), the internet (3\%) and newspapers (2\%)" (Sektor farmaceutyczny stawia na reklamę, 2017). The popularity of television is justified not only by the universal access to the broadcast messages, but also the combination of image and sound, which is what makes audiovisual communication attractive from the point of view of influencing consumer decisions.

On the one hand, normative solutions form a platform for shaping the conditions of trade exchange, fairness of competitive practices, while on the other hand limiting the freedom of economic expression. The catalog of legal solutions eliminates both the ability to recommend products excluded from the market as well as regulating the freedom of economic expression for the products subject to trade exchange.

Advertisers should not only respect media law, but also the specific solutions included in the following:

- Directive 2001/83 / EC of the European Parliament and of the Council of 6 November 2001 on the Community code relating to medicinal products for use in humans (Code of Conduct for Medicinal Products) OJ EU L 311;

- Act of 6 September 2001, Pharmaceutical Law, OJ. 2001 No. 126 pos. 1381 with amendments; 
- Act of 5 December 1996 regarding the profession of physician and dentist, consolidated text OJ 2017 pos. 125;

- Act of 16 April 1993 on Combating Unfair Competition OJ 2003,153,1503, consolidated text with amendments;

- Regulation of the Minister of Health of 21 November 2008 on advertising of medicinal products OJ 08.210.1327.

It should be emphasized that of significant importance are solutions which are a consequence of self-regulation, both professional deontology and codes of ethics, such as the Code of Medical Ethics (Kodeks etyki lekarskiej).

In the first place it should be pointed out that according to the Act of 6 September 2001, of the Pharmaceutical law, the following products cannot be advertised:

- unauthorized for sale in the territory of the Republic of Poland (Article 56 (1) (1));

- containing information not in accordance with the Summary Characteristics of Medicinal Product or of Medicinal Veterinary Product (Article 56 (2));

- issued solely on the basis of prescription (Article 57 (1) (1));

- containing narcotic and psychotropic substances (Article 57 (1) (2));

- included on the list of reimbursable drugs, in accordance with separate regulations, and authorized to be issued without prescription and with names identical with those included on these lists (Article 7 (1) pt (3));

- medicinal products whose names are identical to the name of medicinal products issued only pursuant to a prescription (Article 57 (1a)) excluding protective vaccinations (Article 57 (2));

- medicinal products not meeting established quality requirements; and medicinal products past their expiry date (art 67 (1)).

With the good of the consumer in mind, the legislation unequivocally states that the commercial content:

- cannot be misleading, should present the medicinal product objectively and inform about its rational use (Article 53 (1));

- cannot refer to recommendations of public figures, scientists, persons with medical or pharmaceutical education or implying such education (Article 55 (2));

- cannot imply that: a) it is possible to forego medical advice or surgical procedure, especially by making a diagnosis or recommending treatment by correspondence, $b$ ) even a healthy person taking the me- 
dicinal product will improve their health c) not taking the medicinal product can result in deterioration of a person's state of health - this reservation does not apply to vaccinations referred to in art. $57 \mathrm{sec} .2$, d) the medicinal product is a food, cosmetic or other consumer product, e) the effectiveness or the safety of the medicinal product is due to its natural origin (Article 55 (2) (1));

- cannot provide assurance that taking the medicinal product guarantees the right result, is not accompanied by any adverse effects or that the effect is better or the same as in the case of another method of treatment or treatment with another medicinal product (Article 55 (2);

- cannot lead to erroneous self-diagnosis by citing detailed case descriptions and disease symptoms (Article 55 (2) (3));

- cannot refer to the therapeutic indications in a way that is inappropriate, alarming or misleading (Article 55 (2) (3a));

- cannot include inappropriate, disturbing, or misleading descriptions of graphically presented changes due to illness, injury to the human body or the action of a medicinal product on the human body or its parts (Article 55 (2) (5)).

In addition, the advertisement should include: the name of the medicinal product, the generic name of active ingredient used and, in the case of a medicinal product containing more than 3 active ingredients, the term "combination product;" the dose of active ingredient or its concentration, except for combination products; the pharmaceutical formulation; therapeutic indication or indications for use; contraindications; indication of the subject responsible; compliance with the Summary Product Characteristics or Characteristics of Veterinary Medicinal Product or documentation accepted in the approval process of a medicinal product including the relevant information (Regulation of the Minister of Health of 21 November 2008 on advertising of medicinal products, $\S 6$, par. 1)

Depending on the "product life cycle" phase, either complete or reminder advertising can be utilized. The range of content presented in the latter "in addition to the brand name and generic name of the product may only contain a trademark without reference to therapeutic indications, pharmaceutical formulation, dosage, or advertising slogans or other advertising content" (Art. 53 para 4 of the Pharmaceutical Law). If the subject is the advertising of a traditional herbal medicinal product must include in the communication the following information: "Tradi- 
tional herbal medicine with specific indications resulting solely from history of long-term use" (Rozporządzenie Ministra Zdrowia z dnia 21 sierpnia 2008 r., par. 4, ust. 10). Regardless of the specific features of the pharmaceutical product, each commercial must include a warning: "Before use please read the package insert or consult your doctor or pharmacist, because any medication used improperly threatens your life or health" (Rozporządzenie ministra zdrowia z dnia 21 sierpnia 2008 r., par. 7, ust. 17).

Perhaps the use of the term "message" by the authors of pharmaceutical legislation, was not intentional at the time of constructing the concept, but in the face of the currently accepted interpretation of the term, it constitutes an opportunity for the regulation of audio and audiovisual service, which is the basis for performing an analysis from the point of view of media law. Therefore, the commercial must additionally meet the solutions contained, among others, in the aforementioned Directive 2010/13/EU of the European Parliament and of the Council of 10 March 2010 on the coordination of certain statutory, executive and administrative regulations of member states regarding the provision of audiovisual media services (the Audiovisual Media Services Directive); in the Broadcasting Act on radio and television of 29 December 1992, as well as other acts, which either directly, or while regulating other issues, relate to television advertising. In addition to the general solutions regarding defining the boundaries of advertising messages, it is forbidden to broadcast content that "can encourage conduct endangering health or safety" (Directive 2010/13/EU, Article 9). Specific solutions are contained in national legal regulations. For example, it should be emphasized that from a technical point of view, television advertising must be separated from the rest of the programming in audiovisual and/or visual form in a visible and legible way; and clearly in the aspect of sound (Rozporządzenie ministra zdrowia $\mathrm{z}$ dnia 21 sierpnia 2008 r., par. 6, ust. 2).

Man, as a social being, functions in circles characterized by emotional sensitivity, which is one of the factors of segmentation of the audience market in terms of content construction and selection of information channels. The selection of an appropriate means of communication for a pre-defined audience is the basis for business marketing strategy. In case of pharmaceutical companies, of significant importance is not only the age of the audience, their preferences, but first of all their state of health. 


\section{The Persuasiveness of Pharmaceutical Products Advertising}

The reputation of an organization will be a consequence of positive evaluations from satisfied customers, as a result of satisfying their material needs, as well as created opinions which reinforced the need to acquire a product. It should be remembered that customers and business partners in commercial relationships decide the success of an entity. Therefore, it is the knowledge of marketing department employees, the decisions made in the search for effective solutions to build customer relationships, that determine the market position of an organization. Significant importance is gained both by so called triggers and media through which the message is delivered to potential customers.

Pharmaceutical manufacturers utilize content differentiation for the storylines of product commercials. Most commonly, the scripts display a two part construction. The first part shows a character who is sad, worried, suffering due to pain or an uncomfortable situation, caused by illness or pain affecting the protagonist of the message. The solution to this difficult situation is a "helpful friend" in the form of a person, an animated character, a personified product appearing from outside the shot action, offering an antidote to the ailments. This "someone" is often a friend, a close person, but also a doctor, a pharmacist, a dentist. Due to the trust placed in this individual, the sick person decides to use the recommended product without any additional questions. Its effectiveness is reflected in the state of satisfaction, joy, return to daily activities, and consequently the elimination of disease, discomfort.

The persuasiveness of the message is a derivative of both its verbal and visual dimension. Both the verbiage and the visual aspect of an advertising message can influence the compatibility of consumer behavior with the expectations of the advertiser. The Supreme Court ruling stated that "[...] a message directed at potential consumers relating to goods and services as well as the provider of goods and services and with the aim of encouraging and inducing the recipients to acquire goods or use services. This inducement can be expressed directly, e.g. by the use of expressions corresponding to particular actions, which will result in the sale of goods or services, or indirectly - by creating an enticing image of the goods or services, as well as the provider, to a degree producing in the recipients an irresistible urge to acquire them" (Wyrok SN z dnia 26 stycznia 2006 r.).

Deciding to choose a particular product/service, the customer gains not only a material value, quality, but added value as well, identifying 
expectations of a higher order, including pleasure. B. Dobek-Ostrowska rightly points out that "advertising is a message both informative and persuasive, because the use of both communication techniques increases the effectiveness. The informative message relates to the intellectual component of the recipient. The advertisement equips the recipient with knowledge about the product, service or idea, thus enabling them to make a better choice. If the products are offered at a comparable price, it allows them to purchase a better quality product. [...] As a persuasive message, it is constructed from emotional arguments, it relates to the affective component of the recipient. The advertisement meets their tastes and preferences, warns against samples and substitutes (our product is the best), plays on the price (our product is the best buy), demonstrates a lifestyle (our products are bought by those who are superior and more socially attractive) etc." (Dobek-Ostrowska, 2006, p. 378). The catalog of arguments is not only varied but wide open. Applying: "presupposition, implication, music, colour schemes, presented images of people, values, masking the intent of profit for the sponsor by using the so-called maxim of tact, nostalgia, maxim of magnanimity or maximum of effort for me, homophony, humour, dynamics or statics" (compare: Lewiński, 2008, p. 39 and n.; Barańska, 2011, p. 33 and n.), it influences buyers' decisions.

The verbal dimension is determined by dialogue, monologue, the content of advertising slogan. Conversing protagonists or individuals cast in commercials often emphasize the effectiveness of recommended or used medications, through the use of phrases such as "improved health," "counteracting pain," "pain disappears," "works effectively" they are convincing, also referring to their own experiences. The persuasiveness of the verbal layer of the advertising message content is determined by the phrases utilized, which frequently include information regarding, among others:

- efficacy of the drug perceived as:

a) multi-faceted action, e.g. "Neosine raised the immunity of children to subsequent infections. Neosine - fights viruses, overcomes infections" (GIF nakazat zaprzestania reklamy...), "mobilizes the body to fight" (RUTINOSCORBIN),

b) dose size: "one dose contains the optimal dose of the medicinal ingredient" (CHLORCHINALDIN), "with the maximum dose of the antiviral substance" (OROFAR);

- the effectiveness of the ingredient: "first go to the stomach" (Gel Voltaren Max), "as early as at the age of two months vaccinate your 
child against pneumococci - the most common cause of death of young children worldwide, which can be prevented by vaccination" (Prevenar 13) (Decyzja GIF-P-R-450/13-2/JD/16); "Even for acute sore throat" (Decyzja GIF-P-R-450/78-4/JD/14);

- onset and duration of action: - "significant effect in just 5 minutes" (Instantyl aerosol) (Decyzja GIF-P-R-450/35-6/JD/12), "and Voltaren Max gel - where the pain starts and the only one which lasts for up to 12 hours. See for yourself [...]" (Decyzja GIF-P-R450/15-7/JD/16);

- Product ingredients - "Gripex Hot Active is a composition of ingredients ready for immediate absorption, after drinking it quickly combats all these symptoms" (Decyzja GIF-P-R-450/58-3/JD/12) "natural medicine" (LIPOMAL);

- long-term market presence: "formula tested over the years" (CHLORCHINADIN);

- availability for purchase: "available now without prescription" (FOSIDAL, PULNEO) (more: Prędka, 2015, p. 28-30);

- natural composition - "a rich composition of medicinal herbs directly from nature" (AMOL), "9 medicinal herbs in drops" (IBEROGAST), "natural medicine" (LIPOMAL);

- wide application - "a versatile extraordinary medication for ordinary ailments" (AMOL), "Comprehensively combats bothersome symptoms" (FEBRISAN);

- novelty of the solution - "thanks to revolutionary technology" (APIRIN), "in a scientifically developed formula" (GRIPEX), "the strength of two components" (IBUPROM SINUS), "a modern medicine with triple action"(MUCOSOLVAN), "tri-active formula"(NEO-ANGIN), "a modern heartburn remedy" (ORTANOL), "a modern cold medicine with twice the healing power" (SEPTANAZAL), "thanks to its unique formula" (STREPSILS);

- dosage amount - "the only drug in Poland with the highest dose of ginkgo biloba" (BILOBIL), "one dose contains the optimal dose of medicinal ingredient" (CHLORCHINALDIN), "with the maximum dosage of antiviral ingredient" (OROFAR), "the only one containing as many as three active ingredients" (SUDAFED);

- the duration of market presence - "formula tested over the years" (CHLORCHINADIN);

- current availability without a prescription (FOSIDAL, PULNEO) (Prędka, 2015, p. 30). 
The featured protagonists, the storyline of the commercial, facial expressions, gesticulation, individuals' age, narration, all reinforce and strengthen the credibility of the message. Their behavior and attitudes confirm that health should be identified with this very effective product. Sometimes they tell their own story, which may be an incentive for others with similar complaints to undertake the self-treatment process. It should be noted that campaigns most commonly feature elderly persons who due to their state of health are more likely to purchase products of this type than the younger segments of society. "Older women appear in commercials advertising products alleviating symptoms associated with menopause or urinary incontinence, and very mature men in the advertising of preparations for erectile dysfunction. Moreover, the image of the elderly is used in commercials for other drugs and dietary supplements which help to alleviate ailments associated with old age, and therefore preparations for arthralgias, digestive problems, preparations strengthening the heart. The commercials for medications and dietary supplements educate older people that at a given age the above mentioned ailments may occur and - simultaneously - that their preparations are a perfect remedy for them. Drug advertising messages utilize the recommendation from an 'average' user. The elderly presented in such advertisements are well cared for, cheerful and satisfied with life, surrounded by caring friends, and sometimes even full of vigor and energy" (Kaniewska-Sęba, 2016, p. 153). Their participation in advertising strengthens the credibility of the content delivered.

In the context of the pharmaceutical products campaign, special significance is acquired by product features (formulation: cream, liquid, tablet, capsule, contents of package), and in particular emphasis on its effects. Foreground and background shots featuring the product, illustrating its action and effects through multimedia presentations, e.g. pulsating red spots on the human body symbolizing pain disappearing immediately after consuming the pharmaceutical. The product is not only effective but, unlike its other competitors, it works precisely and quickly. It is rightly noted by B. Pilarczyk that recommendations provided by: ordinary users, experts, celebrities are one of the factors shaping the content of advertising messages. Knowledge, backed up by research results and scientific experience, reinforces the conviction about the offered product quality.

The authority of a physician, pharmacist, physiotherapist, researcher or academic lecturer. The admissibility of "presentation of a medicinal product by public figures, scientists, people with medical or pharmaceu- 
tical education or suggestive of having such education" (Ustawa $\mathrm{z}$ dnia 6 września 2001 r. Prawo farmaceutyczne, art. 55, para. 1, item 1) is conditioned by lack of misleading the consumer. Showing a character dressed in a white coat, equipped with a stethoscope, or a scientist whose title attests to the importance of the content expressed, constitute a frequently used argument in advertising campaigns. Unfortunately, the casting of practicing physicians is ruled out due to the directive of Article 63 of the Medical Ethical Code.

The Polish Supreme Medical Chamber (Naczelna Izba Lekarska - NIL), as the official body supervising the application of beyond-normative solutions by this professional group, initiated proceedings against a physician - Jacek Caba, who according to NIL, while appearing in advertisements as an eye, ear, throat (ENT) specialist, is not actually a medical doctor and does not have the above qualifications, which additionally justifies the disciplinary proceedings. Although the individual concerned denies the charges presented by the NIL in their statement, however, this has not influenced the body to change their position (Sztyler-Turovsky, 2017). Another official body - the Commission on Advertising Ethics, provided a different solution to the matter, by citing the Code of Ethics in Advertising, found that advertising of "Natursept" lollipops, treating sore throat in children, does not apply to a pharmaceutical product, and the actor cast in the role of physician, displaying a badge attached to his coat indicating "Med. Dr" is not in violation of the code of ethics, even given the close-up camera shots of the information provided. Similarly, Ada spoke out on the issue concerning the participation of physicians in advertising, recognizing that "the subject of her evaluation is solely the advertising message as it regards compliance with this code and not the activity of a specific physician in accordance with the principles of medical ethics, because the person featured in the 'Natursept' commercial is in fact a physician and a member of the Medical Chamber" (W reklamie lizaków Natursept...).

In the author's evaluation, the suggestive dimension of the external appearance of the person, the knowledge ascribed to them, related to invoking professional degrees provided verbally or visually, may mislead the viewers. The character presented on the television screen is not an authority, and only by their a way of speaking, the specialized language used, do they imply that the viewers should have faith in their words. Unfortunately, the above circumstances may mislead the recipient. The commercials for "NeoMag Cardio" and "NeoMag Forte" were deemed as 
such, where "the actor was portrayed as a scientist with the title of professor and at the same time an expert on heart conditions, or dietician" (Niby lekarze $w$ reklamach..., 2011).

Engaging celebrities known for their social or professional activities, other than medical, in this type of campaigns occurs occasionally. Jolanta Kwaśniewska recommending "Rutinacea Max," Magda Gessler - "Ulgix Max," Grzegorz Pawlak - voice-over for "Vocaler," - confirm the selection of means of persuasion is decided by the commercial director, the advertiser, but the recipients more willingly accept individuals representing the medical environment.

Many commercial messages present statistics referring to, among other factors, the product consumption, its effectiveness, research results. Deliberately presented are "scientific data, analyses, research results sourced from professional literature or scientific journals with the aim to facilitate the verification and assimilation of information presented in the medicinal product advertising, provided in the original form, citing the source and date of publication or the most recent update" (Rozporządzenie Ministra Zdrowia z dnia 21 listopada 2008 r., § 5).

Management requires that also the timing and duration of airing the advertising material be taken into account. Observation has demonstrated its significance from the point of view of media planning for advertising airtime. In the autumn, winter and spring, the number of commercials recommending the above mentioned goods is higher than in summer time. This is caused by an increase in the occurrence of the common cold and flu, increasing the demand for antipyretics, anti-inflammatories, medications for sore throat, runny nose, such as "NeoAngin," "Strepsils," "Tantum Verde," "Septolete," "Cholisept." Dermatological preparations, contraceptives, diabetic medications, eye drops, ED medications, vaginal preparations and others are recommended all year round.

The responsibility for constructing this type of message content is justified by a specific type of consumer whose sensitivity and critical attitude to the content being delivered is limited. "The main motive for this type of regulation is safeguarding the health and life of citizens, when utilizing medicinal practices" (Barańska, 2012, p. 184).

Selecting a particular product/service, the client acquires not only material value, quality, but also added value, identifying higher order expectations, including pleasure. Actively participating in the process of evaluating the world involves entering in media interactions, watching the 
television messages directed to recipients. The recipient not only verifies the programming offer from the point of view of its subject matter, but also carefully analyzes the audiovisual message.

The visual and verbal characteristics of an advertising commercial combine various elements and levels of persuasion, thus allowing for creation of a specific discourse between the manufacturer, the seller and the potential buyer (cf. Eco, 1968). As motivational vehicles, they activate and direct human activities. Accepting the conveyed content, a person experiences its significance, because they see a reflection of their own existence. The power of its effect is established at the level of conscious and unconscious projection of decision arguments. The transcendence of non-material properties occurs in the materialized image of the notion of happiness, understood through the prism of health, a disease-free state. Regardless of whether the products promoted are painkillers, cold medications, cough suppressants (for wet, dry and undetermined kinds of cough), anxiolytics, antidepressants, preparations for arthritis or hepatic colic, the necessary condition is to appropriately "sell" viewers on the concept of "health." Triggers used in advertising messages correspond to common practices.

\section{Summary}

Modern human beings differ in many ways from their ancestors, both in terms of sociological changes, as well as perceptual experiences. The change in the approach to knowledge acquisition and the way in which contacts are maintained, resulting from the availability of information channels, has contributed to the anthropological transformation. Media became a development area, but as "household members," they joined forces to expand the human mind, to adapt the cognitive, emotional and social mechanisms. In the anthropological sphere not only do they instrumentalize values, but also, in a sense, reinforce the conviction of their importance and significance. The signaled transformations do not, however, modify what is of particular importance to society, what it cares for or strives for.

Values, such as health, family and work have a timeless dimension. For centuries caring for their health has been an important element of human activities, and in recent years this obligation has also been imposed on state organizations. The concept of health defined from a sociological, 
cultural, and other perspectives has also acquired an economic dimension. In anthropological terms, health is classified as a superior value. In the hierarchical valuation system it is ranked in a high position by both individuals and social groups. In the decision-making process it inspires making specific choices as well as justifies actions taken. Such perceived value becomes a reference point, but it also mobilizes, motivates specific behaviors. Values are an instrument, "sense of human desire" (Stoner, Freeman, Gilbert Jr, p. 630), a guide to human effort and positive emotional responses. In caring for their of health, a person undertakes actions that guarantee a positive attitude to their own health and forms of activity. Therefore, referring to them is justified, especially when it comes to advertising messages. Building a storyline, utilizing language designed to identify a product with this value is the result of the advertisers' creativity as well as skillful content management. The native dimension of advertising content management mandates the development of text which, once placed and aired in commercials, will interest the recipient without breaking any rules. The effectiveness of such advertising campaigns is unquestionable.

Poles are willing to buy and take "[...] all manner of medication, parapharmaceuticals and dietary supplements for snoring, throat dryness, restless leg syndrome, dehydration or excess water in the body. Of course, there are also ads for painkillers, colds, cough (wet, dry and undetermined), anxiety, depressive states, arthritis, and hepatic colic. [...] Painkillers/ analgesics alone account for more than 2 billion items annually, of which only $8 \%$ is being prescribed by the doctors" (Policzyliśmy reklamy leków $w T V . . ., 2018$ ). The number of transactions is probably frightening, but at the same time it justifies the effectiveness of that the marketing activities carried out by pharmaceutical companies. According to KRRiT report data (Leki a suplementy diety..., 2016) - "As many as $80 \%$ of Poles are self-medicating and one third buys drugs under the influence of advertising in the media" (KRRiT: sektor farmaceutyczny..., 2017).

In marketing strategies that take into account the goals and aims of consumers, in a sense, participating in the process of guiding an "adult person," pharmaceutical companies confirm their co-responsibility for the wellbeing of an individual, a society. They take on some of the responsibilities of communicating information as well as educating the public about contemporary health risks. Indeed, in this context, describing pharmaceutical products, they point to new disease entities, such as foot mycosis, while offering preventive and curative treatments. This approach 
reinforces the belief that health is valuable not only from the perspective of the individual but also the organization, although the approach varies in terms of interpretation, goals as well as the means of adapting them for development.

Instrumentalization of health in advertising on the one hand influences the sensitivity of the recipient, their behavior and attitudes, and, on the other hand, from the organizational perspective, it has a commercial dimension. Nevertheless, it should be emphasized that despite everything, the essence of advertising lies in the individual's freedom of choice. This, however, does not equal the unrestricted utilization of the means of persuasion. Advertisers must keep in mind the integrity of the message content, and therefore the commercials must not be misleading. Acting according to expectations, the advertiser confirms the validity of the arguments used in the message content.

However, the practical dimension of normative solutions justifies the necessity for introducing changes in the future. There is a need to verify the law from the perspective of introducing provisions requiring a precise characteristics of a product classified as a pharmaceutical versus a dietary supplement. The inadequate current level of knowledge in the Polish society regarding the product classification justifies not only the need for an educational process but the development of separate solutions, especially for promoting the latter. In addition, this postulate is a consequence of the duality of the offer to sell a drug and a supplement by the same name, which can mislead the buyer.

As a result, health is not an absolute, but a consequence of trusting those able to point to a trustworthy argument. The number of transactions may certainly be frightening, but at the same time it justifies the effectiveness of marketing activities conducted by pharmaceutical companies. Buyers looking after their health accept the products promoted in advertisements, considering them a guarantee of a disease-free condition.

1. See: The Constitution of the World Health Organization, an agreement concluded by the Governments represented at the International Health Conference and the Protocol regarding the International Office of Hygiene, signed in New York on July 22, 1946; 1948, Nr 61, pos. 477; International Covenant of Civil and Political Rights, O.J. 1977 No. 38, item. 167; Resolution "Health for All."

2. Adopted by the World Health Assembly devoted to Alma-Ata Primary Health Care, former USSR, September 6-12, 1978. 
3. Article $1 \mathrm{~h}$ of the Directive of the European Parliament and Council of 10 March 2010, 2010/13/EU, regarding the coordination of certain legislative, regulatory and administrative regulations of the Member States concerning the provision of audiovisual media services (Audiovisual Services Directive) states that 'commercial audio visual communication' signifies visual materials with or without a sound component, which are intended to directly or indirectly promote the goods, services or image of a physical person or legal entity conducting a business activity. These images accompany the broadcast or are placed in it, in exchange for a fee or similar remuneration, for the purposes self-promotion. Forms of commercial audiovisual communication include: television advertising, sponsorship, teleshopping and product placement."

4. It should be borne in mind that the following should not be included in the advertisements: the information on the packaging and the medicinal products accompanying the marketing authorization package (paragraph 3 (1)); Correspondence accompanied by non-promotional information material necessary to answer questions about a particular medicinal product, including a medicinal product authorized without the authorization required by Art. 4 (par. 3 point 3); notices of informational nature not publicly available concerning, in particular, changes in packaging, warnings of adverse reactions, provided that they do not contain content relating to the characteristics of medicinal products (paragraph 3 (4)); commercial directories or price lists containing only the generic name, common name, dosage, form and price of the medicinal product, including the authorized medicinal product without the authorization required by art. 4 and, in the case of a refundable medicinal product, the official retail price, provided that they do not contain content relating to the characteristics of the medicinal product, including therapeutic indications (paragraph 3 (5)); Information on the health or diseases of humans and animals, provided that they do not relate indirectly to medicinal products (paragraph $3(6)$ ).

5. The term is used in legal acts to designate services provided by radio, television and the Internet.

6. An example is the Regulation of the National Broadcasting Council of 30 June 2011 on how to conduct radio and television advertising and teleshopping activities. U. 2014, item no. 204.

7. Commercial audiovisual communications: must not violate human dignity; may not contain any discriminatory content on grounds of sex, race or ethnic origin, nationality, religion or belief, disability, age or sexual orientation, or promote such discrimination; can not encourage health or sa- 
fety-threatening behavior; can not encourage behavior that would seriously harm the environment (Article 9 of Directive 2010/13/EU); audiovisual communication on prescription-only medicinal products and treatments in the Member State within whose jurisdiction the media service provider is subject (Article 9 of the above mentioned Act) must not cause physical or moral injury to minors. As a result, they can not directly induce minors to buy or rent a product or service, using their lack of experience or credulity, they can not directly encourage minors to persuade parents or third parties to buy the advertised product or service, can not use the special trust the minors have in their parents, teachers or others, or may without justification show minors in dangerous situations (Article $9(\mathrm{~g})$ of the above mentioned Act); must not contain content that could seriously harm the physical, mental or moral development of minors, in particular pornographic or unjustified programs (Article 27 of the above mentioned Act).

\section{Bibliography}

\section{Legal acts:}

International Covenant on Civil and Political Rights opened for signature in New York on 19 December 1966, OJ 1977 No. 38, pos. 167.

Universal Declaration of Human Rights, G.A. Res. 217A (III), U.N. GAOR, 3d Sess., 1st plen. mtg., U.N. Doc. A/810 (Dec. 10, 1948).

Act of 5 December 1996 regarding the profession of physician and dentist, Consolidated text OJ 2017, pos. 125.

Directive 2001/83 / EC of the European Parliament and of the Council of 6 November 2001 on the Community code relating to medicinal products for use in humans (Code of Conduct for Medicinal Products), OJ EU L 311.

Directive 2010/13 / EU of the European Parliament and of the Council of 10 March 2010 on the coordination of certain provisions laid down by law, regulation or administrative action in Member States concerning the provision of audiovisual media services (Audiovisual Media Services Directive, OJ L 95/15).

Ustawa dnia 29 grudnia 1992 r. o radiofonii i telewizji, Dz. U. 2017, Nr 33, poz. 1414.

Rozporządzenie Ministra Zdrowia z dnia 21 listopada 2008 r. w sprawie reklamy produktów leczniczych, Dz. U. 2008, Nr 45, poz. 271.

Ustawa z dnia 6 września 2001 r. Prawo farmaceutyczne, t.j. Dz. U. 2016, Nr 183, poz. 2142.

Rozporządzenie Krajowej Rady Radiofonii i Telewizji z dnia 30 czerwca $2011 \mathrm{r}$. w sprawie sposobu prowadzenia w programach radiowych i telewizyjnych działalności reklamowej i telesprzedaży, Dz. U. 2014, nr 0, poz. 204. 


\section{Court rulings:}

Wyrok SN z dnia 26 stycznia 2006 r. w sprawie V CSK 83/05 (Judgment of the Supreme Court dated 26 January 2006 in case V CSK 83/05).

\section{Decisions:}

Decyzja GIF-P-R-450/13-2/JD/16.

Decyzja GIF-P-R-450/15-7/JD/16.

Decyzja GIF-P-R-450/35-6/JD/12.

Decyzja GIF-P-R-450/58-3/JD/12.

Decyzja GIF-P-R-450/78-4/JD/14.

\section{Non-normative acts:}

Kodeks etyki lekarskiej, http://www.nil.org.pl/_data/assets/pdf_file/0003/4764/ Kodeks-Etyki-Lekarskiej.pdf, 2.05.2017.

\section{Publikacje:}

Armstrong M. (1998), Zarządzanie zasobami ludzkimi. Strategia i działania, Kraków.

Arytoteles (1972), O duszy, Warszawa.

Bakalarska J. (2016), Marketing wartości, Lublin.

Barańska M. (2011), Reklama i jej ograniczenia. Standardy europejskie a prawo polskie, Warszawa.

Barańska M. (2012), Polityka ograniczania reklamy w polskiej telewizji. Studium politologiczno-prawne, Poznań.

Barańska M. (2016), Zarządzanie wartościa zdrowia w marketingu na przyktadzie wybranych reklam koncernów farmaceutycznych, "Środkowoeuropejskie Studia Polityczne", nr 3.

Blanchard K. (2015), Zarządzanie przez wartości, Warszawa.

Dobek-Ostrowska B. (2006), Komunikowanie polityczne i publiczne, Warszawa.

Dobiegała-Korona B. (2006), Wartość klienta czy wartość dla klienta, "Kwartalnik Nauk o Przedsiębiorstwie", nr 1.

Dobiegała-Korona B. (2012), Nowa rola marketingu $w$ budowie wartości przedsiębiorstwa. "Kwartalnik Nauki o Przedsiębiorstwie", nr 2.

Doyle P. (2003), Marketing wartości, Warszawa.

Eco U. (1968), Pejzaż semiotyczny, Warszawa.

GIF nakazat zaprzestania reklamy telewizyjnej syropu dla dzieci Neosine, http:// wyborcza.biz/biznes/1,147743,19733216,gif-akazal-zaprzestania-reklamytelewizyjnej-syropu-dla-dzieci.html, 4.05.2017.

Górniak L. (2015), Zarządzanie przez wartości jako metoda angażowania pracowników, "Zeszyty Naukowe UEK”, nr 8. 
Harasimiuk D. E. (2011), Zakazy reklamy towarów w prawie europejskim, Warszawa.

Hofstede G. (2000), Kultury i organizacje. Zaprogramowanie umystu, Warszawa.

Jarosz-Żukowska S. (2014), Prawo do ochrony zdrowia i dostępu doświadczeń opieki zdrowotnej, w: Realizacja i ochrona konstytucyjnych wolności i praw jednostki w polskim porządku prawnym, red. M. Jabłoński, Wrocław.

Kaniewska-Sęba A. (2016), Polscy seniorzy - wyzwanie dla marketingu w XXI wieku, "Środkowoeuropejskie Studia Polityczne", nr 4.

Kocik L. (2006), Rodzina w obliczu wartości i wzorów życia ponowoczesnego świata, Kraków.

Kotler Ph., Armstrong G., Saunders J., Wong V. (2001), Principle of Marketing, St. Louise.

KRRiT: sektor farmaceutyczny najbardziej reklamowana branża, 10.04.2017, http:// www.rynekaptek.pl/marketing-i-zarzadzanie/krrit-sektor-farmaceutycznynajbardziej-reklamowana-branza,19520.html, 10.05.2017.

Kumar V. (2010), Zarzadzanie wartością klienta, Warszawa.

Leki a suplementy diety. Raport KRRiT, 25.04.2016, http:/www.krrit.gov.pl/krrit/aktualnosci/news,2265,leki-a-suplementy-diety-w-reklamach.html, 10.05.2017.

Lewiński P. H. (2008), Retoryka reklamy, Wrocław.

Marketing wartości, http://kolegia.sgh.waw.pl/p1/KNoP/struktura/IZW/struktura/ zmw/Strony/Marketing-wartosci.aspx.

Mobile i digital w Polsce i na świecie w 2016 r., 27.01.2016, https://mobirank.pl/ 2016/01/27/mobile-digital-w-polsce-na-swiecie-2016/, 3.05.2017.

Niby lekarze w reklamach wprowadzaja konsumentów błą, 6.08.2011, http://www. nowiny24.pl/strefa-biznesu/prawo-i-podatki/a/niby-lekarze-w-reklamachwprowadzaja-konsumentow-blad,10279082, 2.05.2017.

Nierenberg B. (2011), Zarządzanie mediami. Ujęcie systemowe, Kraków.

Olechnicki K., Załęcki P. (1997), Słownik socjologiczny, Toruń.

Plopa W. (2009), Wartości a politycy, Kraków.

Polacy coraz dtużej oglądaja telewizję, mniej czasu poświęcaja prasie, radio króluje przed poludniem, 14.06.2016, http://www.wirtualnemedia.pl/artykul/polacy-coraz-dluzej-ogladaja-telewizje-mniej-czasuposwiecaja-prasie-radio-kroluje-przed-poludniem, 4.05.2017.

Policzyliśmy reklamy leków w TV - liczba przeraża!, 25.04.2016, http://akademiaporodu.pl/blog/reklamy-lekow-w-telewizji/, 9.05.2017.

Prędka E. (2015), Emisja przekazów handlowych produktów zdrowotnych i leków w programach telewizyjnych. Raport, Warszawa.

Prymon M. (2001), Wspótczesne badania marketingowe, Lublin.

Rynek i reklama leków w programach telewizyjnych, https://efarmaceuta.pl/uploads/ media/5ed53320d7d63dfb50b8a1cb29242410c88d18953ae56fcfcab6ffc7286 a9b05.jpg, 4.05.2017. 
Sektor farmaceutyczny stawia na reklame, 2.01.2017, http://pulsfarmacji.pl/4653007, 99742,sektor-farmaceutyczny-stawia-na-reklame, 6.05.2017.

Stownik biznesu i ekonomii, hasło: zarzadzanie marketingowe, http://www.biznesowe. edu.pl/609-zarzadzanie_marketingowe/, 1.05.2017.

Stownik tacińsko-polski (1982), red. H. Menge, H. Kopia, oprac. K. Komaniecki, Olsztyn.

Stachowicz-Stanusch A. (2004), Zarządzanie przez wartości. Perspektywa rozwoju wspótczesnego przedsiębiorstwa, Gliwice.

Stoner J. A. F., Freeman R. E., Gilbert Jr D. R. (2001), Kierowanie, Warszawa.

Sudak I., KRRiT: gigantyczna liczba reklam i suplementów, 26.04.2016, http:// wyborcza.biz/biznes/1,147743,19979014,krrit-gigantyczna-liczba-reklamlekow-i-suplementow.html, 16.05.2017.

Sztucki T. (1998), Encyklopedia marketingu, Warszawa.

Sztyler-Turovsky A., Lekarze karani za udziat w reklamach, http://www.medonet.p1/ zdrowie/zdrowie-dla-azdego,lekarze-karani-za-udzial-w-reklamach--koniecreklam-suplementow-diety,artykul,1721461.html, 1.05.2017.

Trzaska M. (2011 ), Zarządzanie treścia, Warszawa.

$W$ reklamie lizaków Natursept może występować lekarz, bo to nie produkt leczniczy, 31.03.2015, http://www.wirtualnemedia.pl/artykul/w-reklamie-lizakow-natursept-moze-wystepowac-lekarz-bo-to-nie-produkt-leczniczy-wideo, 3.05.2017.

Wartości i normy. Badanie przeprowadzone przez Centrum Badania Opinii Społecznej (2013), nr BS/111/2013, Warszawa.

Wartości i zaufanie spoteczne w Polsce w 2015 r., Główny Urząd Statyczny, Warszawa, 20.11.2015.

Wspótczesna definicja zdrowia WHO, http://www.seremet.org/who_zdrowie.html, 3.05.2017.

\section{Zarządzanie treścią w reklamie telewizyjnej na przykładzie wartości zdrowia}

\section{Streszczenie}

Świat, w którym żyje człowiek jest zbiorem wartości, utworzonych przez niego i dla niego. Jako istota wolna, dokonuje ich wyboru, kieruje się nimi w codziennych zachowaniach, postawach, uznając za cenne, godne wysiłku. Uznane społecznie czy indywidualnie wpływają na decyzje podejmowane w sferach: ekonomicznej, estetycznej, moralnej, prawnej, poznawczej czy religijnej. Ich doniosłość i wpływ zauważyli także autorzy komunikatów reklamowych. Odpowiednio dobrane dla danego rynku, kształtują treść komunikatów reklamowych i mają znaczenie w komunikacji przedsiębiorstwa z konsumentami. Szczególnie zaobserwować to można w przeka- 
zach rekomendujących leki. Odwoływanie się czy powoływanie wartości szczególnie cenionej, jaką jest „zdrowie”, jest nie tylko uzasadnione, ale pozwala nabywcom na dokonywanie wyboru tych produktów, które w ich ocenie gwarantują osiągnięcie dobrostanu, stanu bezchorobowego. Zarządzanie treścią reklamy poprzez swoistego rodzaju „obrazowanie” zdrowia w reklamach jest konsekwencją stosowania różnych środków perswazyjnych.

Słowa kluczowe: zarządzanie marketingiem, wartość, zdrowie, reklama telewizyjna 